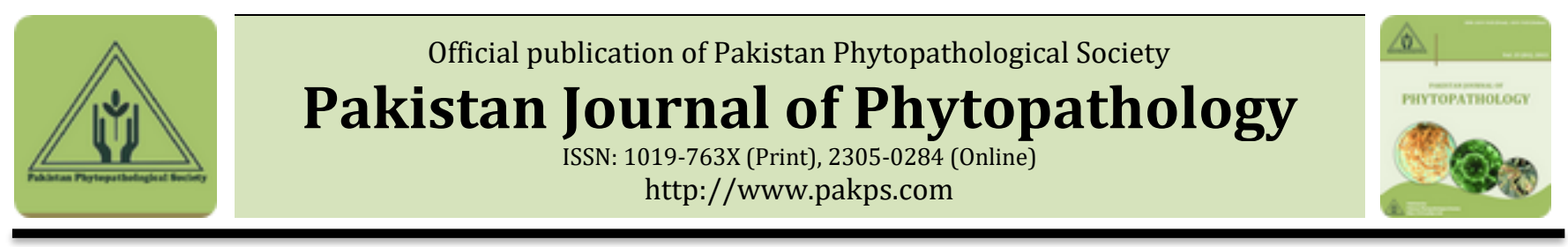

\title{
RESISTANCE ASSESSMENT OF TOMATO (SOLANUM LYCOPERSICUM L.) AND GBOMA (SOLANUM MACROCARPON L.) CULTIVARS AGAINST BACTERIAL WILT CAUSED BY RALSTONIA SOLANACEARUM IN BENIN
}

\author{
${ }^{a}$ Ghislain F. G. N. Oussou, aRachidatou Sikirou*, bSètondji A. P. E. Afoha, aMarie E. E. A. Dossoumou, \\ aSharif A. Boukari, cFrançoise A. Komlan, aBruno Zocli \\ ${ }^{a}$ Laboratory of Crop Protection, Center of Agricultural Research of Agonkanmey (CRA-Agonkanmey), \\ National Institute of Agricultural Research of Benin (INRAB), Benin. \\ ${ }^{b}$ Laboratory of Biotechnology, Genetic Resources and Animal and Plant Breeding of the National University of Sciences, \\ Technologies, Engineering and Mathematics, Benin. \\ ${ }^{c}$ Center of Agricultural Research of Perennial Plants of Pobè (CRA-PP), National Institute of Agricultural Research of \\ Benin (INRAB), Benin.
}

\begin{abstract}
A B S T R A C T
Bacterial wilt caused by Ralstonia solanacearum is the devastating disease of Solanaceaeous plants including tomato and Gboma in Benin. To find out resistant cultivars against bacterial wilt, nine tomato and seven Gboma cultivars were screened in glasshouse in a completely randomized block design with 3 replications. Tomato plants were inoculated by crown region inundation with $40 \mathrm{ml}$ of $10^{8} \mathrm{CFU} / \mathrm{ml}$ bacterial suspension of the strain 19bLDC Phylotype 1 of $R$. solanacearum four weeks after transplanting while Gboma plants were inoculated after scarification of their roots with the strain 5aLDC Phylotype 1. Two weeks after transplanting, it was found that tomato cultivars HW7996 and PADMA were highly resistant; Platinum was resistant; Jalani, Thorgal and Mongal were moderately resistant; Nirvana was moderately susceptible (MS) and Tohounvi and TLCV15 were susceptible (S). Gboma cultivar AUB3G was appeared as resistant to R. solanacearum, cultivars Gboma Athiémé, Gboma PCM, CR1-01-001, CR1-13-049 and BOC15 were susceptible (S) and Gboma-teck was highly susceptible. It can be concluded that tomato cultivars PADMA and HW7996 and that of Gboma AUB3G were resistant to R. solanacearum. All cultivars were colonized with bacterial inoculum. Considering that resistant plants also harbor the disease, growers should practice sanitation as well for both susceptible and resistant cultivars. The resistant cultivars identified will be an important component in the management of bacterial wilt of tomatoes and Gboma and will be disseminated to farmers. They will serve as basic data for breeders and seed production firms.
\end{abstract}

Keywords: Disease of solanaceaeous, Management, germplam screening.

\section{INTRODUCTION}

Vegetables production has become an activity that responds effectively to urban food demand in Benin (Simeni et al., 2009). These are sociologically and economically important for the population (Assogba Komlan et al., 2007). Vegetable sub-sector employs

\section{Submitted: November 30, 2020}

Revised: December 02, 2020

Accepted for Publication: December 20,2020

* Corresponding Author:

Email: rachidatous@yahoo.fr

(C) 2017 Pak. J. Phytopathol. All rights reserved. many people in Benin. The income generated by vegetable production allows many thousands dozen of families to survive (Sikirou et al., 2001). Vegetable play also an important role in the diet of populations, contribute to the prevention of diseases due to micronutrient deficiencies (Olaniyi et al., 2010) and reduce the risks of cancer and cardiovascular diseases (Bhowmik et al., 2012). Many local and exotic vegetables are grown in West Africa (James et al., 2010). Among these, tomato (Solanum lycopersium) and the African nightshade (Solanum macrocarpum) commonly known as "Gboma" are the main fruit and leaf vegetables 
cultivated, consumed and commercialized in Benin. These are an important source of income for farmers especially during the off-season (Assogba Komlan et al., 2007).

Tomato and Gboma are produced along the year (rainy season and off-season) in all agro-ecological zones of Benin (Sikirou, 2011) where several local and improved varieties are cultivated by farmers. Tomato and Gboma production fell drastically in the southern areas of Benin where tomato yield was reduced by $91.9 \%$ between 1999 and 2004 in the Ouémé valley (Sikirou et al., 2017). These drops in production are due to the pressure of many fungal (Sikirou et al., 2015a), bacterial (IdrissouTouré et al., 2017), virus (Hanssen et al., 2010) diseases and nematodes (Pereira-Carvalho et al., 2010; Affokpon, 2011). In Benin, the bacterial wilt caused by the soilborne bacterium $R$. solanacearum is a major constraint in the production Solanaceaeous plants. Bacterial wilt has reduced the production of Solanaceae in some areas of Benin where an incidence of $72 \%$ has been recorded for tomato (Sikirou et al. 2017) and 75\% for Gboma (Sikirou et al. 2017; Sikirou et al. 2015b). In recent years, an upsurge in bacterial wilt of Solanaceae has been observed in the main tomato production areas (Sikirou et al., 2009) and Gboma (Sikirou et al., 2015b) particularly in southern Benin. Yield losses caused by $R$. solanacearum vary according to country, agroecological zone and crop (Tengku Abul Malik et al., 2012; Muthoni et al., 2012; Habetewold et al., 2015). In the United States of America, $R$. solanacearum is one of the potentially arms usable as bioterrorism (Madden and Wheelis, 2003; Hong et al., 2012). This pathogen has affected the productivity of more than 80 countries Table 1. Crops seeds origins

\begin{tabular}{lll}
\hline Crops & \multicolumn{1}{c}{ Cultivars } & \multicolumn{1}{c}{ Origins } \\
\hline \multirow{3}{*}{ Tomato } & $\begin{array}{l}\text { Platinum, Jalani, Nirvana, PADMA } \\
\text { and TLCV15 }\end{array}$ & International Fertilizer Development Center (IFDC) \\
\cline { 2 - 3 } & Thorgal and Mongal & Purchased from "Bénin semence" \\
\cline { 2 - 3 } & Tohounvi & $\begin{array}{l}\text { Vegetable Program of National Agricultural Research Institute of } \\
\text { Benin PCM/INRAB }\end{array}$ \\
\cline { 2 - 3 } & HW7996 & $\begin{array}{l}\text { Centre International de Recherche pour l'Agriculture et le } \\
\text { Développement (CIRAD) }\end{array}$ \\
\cline { 2 - 3 } Gboma & CRI-13-049 and CRI-01-001 & National Agricultural Research Center CNRA/ Ivory Coast \\
\cline { 2 - 3 } & Gboma-teck and Gboma-Athiémé & Crops Research Institute of Ghana (CRI) \\
\cline { 2 - 3 } & Gboma-PCM & $\begin{array}{l}\text { Vegetable Program of National Agricultural Research Institute of } \\
\text { Benin PCM/INRAB }\end{array}$ \\
\hline
\end{tabular}

Experiments conditions and experimental design:

The experiments reported here were conducted twice worldwide leading to a loss of $90.62 \%$ under high incidence (Artal et al., 2012). The complexity associated with $R$. solanacearum adaptability, viability and diversity makes its management very difficult (Subedi, 2014).

However, management approaches have been developed. They include sanitation (Aslam et al., 2017), grafting (Comes et al., 2009; Rivard et al., 2012), the use of disease reducing plants like Alliaceae which are efficient bio-fumigant and sanitizing plants (Debert et al., 2014) and crop systems by rotating or mixing none susceptible different crops (Kakuhenzire et al., 2013; Getachew and Chemeda, 2016). Unfortunately, pesticides targeting bacteria are rare and experimental efforts still continue to be made (Boshou et al., 2005; Balestra et al., 2009). Separately, neither of these methods is effective enough.

The control of this disease is mainly based on varietal resistance, which is the most effective management strategy, environment friendly and cost effective for farmers and consumers. In Benin, no information is available on the genetic assessment of tomato and Gboma cultivars to bacterial wilt. The objective of this study is to assess the resistance of tomato and Gboma cultivars against bacterial wilt.

\section{MATERIALS AND METHODS}

Germplasm collection: Tomato and Gboma germplasm were collected from different institutions, programs, farmers or purchased from a local certified seeds market (Table 1). Tomato cv. Tohounvi was the susceptible check line (Sikirou et al., 2009) and HW7996 was the resistant one (Wicker et al., 2009). The Gboma cv. PCM was the susceptible check line. No resistant check line was considered in Gboma. Protection (LDC) at the National Institute of Agricultural 
Research of Benin (INRAB) located at Abomey-Calavi in Southern Benin ( $\left.6^{\circ} 24^{\prime} 35 \mathrm{~N}, 2^{\circ} 19^{\prime} 56 \mathrm{E}\right)$. The nurseries of the tomato and Gboma cultivars were raised separately in germination trays filled with previously sterilized soil for 1 hour at $80^{\circ} \mathrm{C}$. The daily temperature ranged from $26.5^{\circ} \mathrm{C}-28{ }^{\circ} \mathrm{C}$ for the first trial and from $29{ }^{\circ} \mathrm{C}-30{ }^{\circ} \mathrm{C}$ for the second. Inoculated plants were arranged in a completely randomized block design with three (3) replications. Experiments were conducted during the rainy and the dry season to compare plants reaction under low and high temperature.

Inoculum preparation and plants inoculation: The inoculum were prepared at a concentration of $10^{8} \mathrm{cfu}$ $\mathrm{ml}^{-1}$ (colony-forming unit per milliliter) from the strains 19bLDC and 5aLDC of $R$. solanacearum both Phylotype 1 and of molecular characteristic ST (eg. ST43 (sequevar 31), must obtained from the Laboratory of Crop Protection (LDC) of INRAB. Four (4) week old tomato plants were transplanted after roots wounding and inoculated the same day through soil drenching with 40 $\mathrm{ml}$ of an inoculum per plant by the method of collar flooding. Due to the slow development of the root system, Gboma plants were inoculated two (2) weeks later ( 6 weeks old age) after root scarification (Vasse et al., 1995; Sikirou et al., 2009). After inoculation, each plant was watered daily with $100 \mathrm{ml}$ of water and symptoms of bacterial wilt were observed. Control plants were applied with distilled water.

Colonization of tomato and Gboma plants by $R$. solanacearum: Latent infection of unwilted tomato and Table 2. Classification of resistance level to bacterial wilt based on disease incidence

The one-way analysis of variance from $\mathrm{R}$ software, version 3.5.2 was used. It was focused on the bacterial

\begin{tabular}{|c|c|}
\hline Reaction & Disease incidence \\
\hline Highly Resistant (HR) & $0 \%$ wilted plant \\
\hline Resistant (R) & $1-10 \%$ wilted plants \\
\hline Moderately Resistant (MR) & $>10-20 \%$ wilted plants \\
\hline Moderately Susceptible (MS) & $>20-30 \%$ wilted plants \\
\hline Susceptible (S) & $>30-70 \%$ wilted plants \\
\hline Highly Susceptible (HS) & $>70 \%$ wilted plants \\
\hline $\begin{array}{l}\text { The area under bacterial wilt incidence progress } \\
\text { curve: The area under bacterial wilt incidence progress } \\
\text { curve (AUIbwPC) is a function of time. AUIbw } \mathrm{PC}=\mathrm{f}(\mathrm{t}) \\
\text { (Jeger and Viljanen-Rollinson, 2001). It is calculated }\end{array}$ & $\begin{array}{l}\text { wilt incidence, the bacterial colonization index and } \\
\text { AUIbwPC. Means were classified into homogeneous } \\
\text { groups using Student-Newman-Keuls test at the } 5 \% \text {. } \\
\text { RESULTS }\end{array}$ \\
\hline $\begin{array}{l}\text { according to the following formula: } \\
\qquad \text { AUI }_{b w} P C=\sum_{i=1}^{k}\left[\left(I F B_{i}+I F B_{i+1}\right)\left(t_{i+1}-t_{i}\right)\right] / 2 \\
\text { bw }=\text { bacterial wilt, } B W I=\text { Bacterial Wilt Incidence }\end{array}$ & $\begin{array}{l}\text { Response of tomato cultivar to Ralstonia } \\
\text { solanacearum: The incidence of bacterial wilt, the } \\
\text { percentage of colonized plants by } R \text {. solanacearum and the }\end{array}$ \\
\hline STATISTICAL ANALYSIS & area under bacterial wilt incidence progress curve \\
\hline $\begin{array}{l}\text { The one-way analysis of variance from } R \text { software, } \\
\text { version } 3.5 .2 \text { was used. It was focused on the bacterial }\end{array}$ & $\begin{array}{l}\text { (AUIbwPC) varied among tomato cultivars (Table } 2) \text {. The } \\
\text { incidence was highly significant }(\mathrm{P}<0.001) \text { between the }\end{array}$ \\
\hline
\end{tabular}

Gboma plants was determined at $28^{\text {th }}$ days after inoculation (DAI) by cutting the stem section of 2 to $3 \mathrm{~cm}$ per plant at $1 \mathrm{~cm}$ above the crown region. Each section was disinfected with $70 \%$ ethanol and then inflamed with $90 \%$ ethanol. The colonization test of tomato plant by the bacterium was performed using the imprint of the base of the section on the SMSA (Semi Selective Medium of South Africa) plate. For Gboma plants, the colonization was verified by macerating and plating on the SMSA medium according to the modified method of Elphinstone et al. (1996) at the rate of five imprints per plant. Plates were incubated for 72 hours at $28{ }^{\circ} \mathrm{C}$. The appearance of $R$. solanacearum colonies on SMSA plate allowed to calculate the Bacterial Colonization Index (BCIx) according to the following formula:

$\mathrm{BCIx}=100 *(\mathrm{Pf}+\mathrm{Pc}) / \mathrm{N}$ with

$\mathrm{Pf}=$ number of wilted plants at $28 \mathrm{DAI} ; \mathrm{CP}=$ number of colonized plant at $28 \mathrm{DAI} ; \mathrm{N}=$ Total number of inoculated plants.

Incidence of bacterial wilt: The incidence of bacterial wilt (IBW) was calculated as the ratio of the number of wilted plants (NWP) and that of inoculated plants (NIP) by the following formula:

IBW $=(\mathrm{NWP} / \mathrm{NIP}) \mathrm{x} 100$.

According to the classical scale of 1 = died plant, completely wilted plant or three quarters wilted plant and $0=$ symptomless.

The classification level of resistance to bacterial wilt based on disease incidence according to Mew and Ho (1977) as referred to Table 2 was used. 
nine tomato cultivars during the two experiments. During the first one, the $\mathrm{cv}$. Tohounvi was the most susceptible to bacterial wilt with $70 \%$ of wilted plants followed by the cv. TLCV15 for which $43.33 \%$ of wilted plants were recorded. Wilt was moderate for Mongal (6.66\%), Thorgal (10\%), Jalani $20 \%)$ and Nirvana (23.33\%) cultivars, very low for Platinum (3.33\%) and null (0\%) for PADMA and HW7996 which did not show any wilted plants. During the 2nd experiment, the wilting trend was similar to that of the first experiment with an increasing of the incidence for more than $66 \%$ of cultivars.

All varieties were colonized with $R$. solanacearum strain 19bLDC including the resistant test line HW7996. In addition, the colonization percentage increased during the 2nd experiment for the majority of the tested cultivars. Regarding AUIbwPC, the analysis of variance Table 3. Bacterial wilt incidence, index of colonization and area under bacterial wilt incidence progress curve of nine tomato cultivars

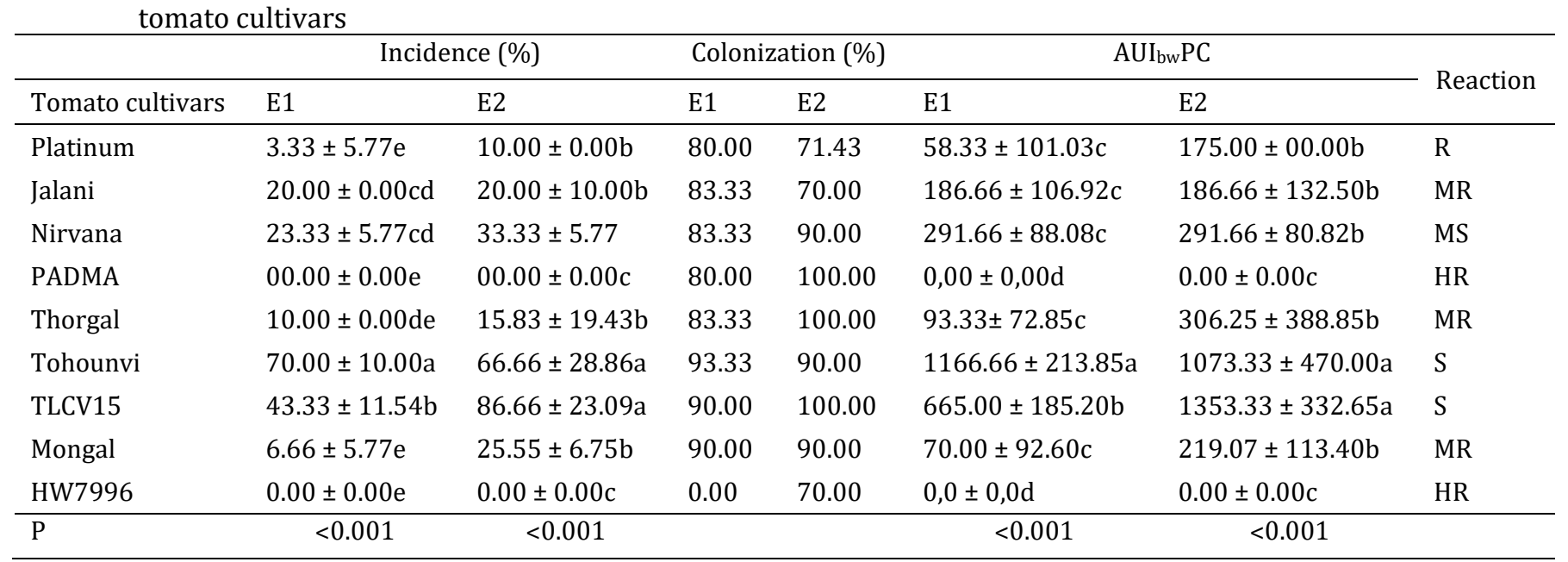

Means within column with the same letters are not significantly different according to Student-Newmann-Keuls test with $\mathrm{P}=0.05 . \mathrm{E}=$ Experimentation

Response of Gboma cultivar to Ralstonia solanacearum: During the two experiments with Gboma, significant variability between cultivars was recorded for bacterial wilt incidence $(\mathrm{P}<0.05 ; \mathrm{P}<0.001)$, the AUIbwPC $(\mathrm{P}<0.05 ; \mathrm{P}<0.01)$ and percentage of colonized plants (Table 4). The highest incidence of wilted plants was recorded in cv. Gboma-teck (41.67\%; 83.33\%) followed by the GbomaPCM (23.33\%; 50\%) in both experiments. The cv. AUB3G (8.33\%; 10\%) showed the lowest incidences. The disease incidence of cv. BOC15 (6.67\%; 46.66\%), CR1-13-049 (8.33\%; 60.66\%), CR1-01-001 (15.37\%; 50\%) and GbomaAthiémé $(15.83 \% ; 36.66 \%)$ are in middle (Table 4). The AUlbwPC varied significantly ( $\mathrm{P}<0.05 ; \mathrm{P}<0.001$ ) between cultivars of Gboma and shown similar trends to those of the incidences of bacterial wilt. The highest AUIbwPC values showed a highly significant difference $(\mathrm{P}<0.001)$ between the nine cultivars during the two experiments (Table 3). The highest AUIbwPC were noted for the cv. Tohounvi (1166.66 and 1073.33) followed by TLCV15 (665 and 1353.33) and the lowest was noted for Platinum (58.33 and 175.00). The AUIbwPC was null (0) for PADMA and HW7996 during the two experiments.

During the 2nd experiment, an increasing in the AUIbwPC was recorded for more than $50 \%$ of the tested cultivars. Based on the responses of tomato cultivars to bacterial wilt induced by the strain of $R$. solanacearum 19bLDC, the cvs. PADMA and HW7996 were highly resistant and Platinum was resistant. This resistance was moderate for cvs. Jalani, Thorgal and Mongal. In contrast, cv. Nirvana was moderately susceptible and cvs. Tohounvi and TLCV15 were susceptible. 
Table 4. Bacterial wilt incidence, index of colonization and area under bacterial wilt incidence progress curve of seven Gboma cultivars

\begin{tabular}{|c|c|c|c|c|c|c|c|}
\hline \multirow{2}{*}{ Gboma cultivars } & \multicolumn{2}{|c|}{ Incidence (\%) } & \multicolumn{2}{|c|}{ Colonization (\%) } & \multicolumn{2}{|c|}{$\mathrm{AUI}_{\mathrm{bw}} \mathrm{PC}$} & \multirow{2}{*}{ Reactions } \\
\hline & E1 & E2 & E1 & E2 & E1 & E2 & \\
\hline Gboma-teck & $41.67 \pm 14.43 \mathrm{a}$ & $83.33 \pm 15.27 a$ & 45.83 & 100.00 & $583.33 \pm 91.07 a$ & $1061.66 \pm 297.67 \mathrm{a}$ & HS \\
\hline Gboma-Athiémé & $15.83 \pm 19.41 b$ & $36.66 \pm 5.77 b$ & 16.66 & 43.33 & $224.58 \pm 30.64 b$ & $478.33 \pm 199.01 b$ & S \\
\hline AUB3G & $8.33 \pm 14.43 b$ & $10.00 \pm 10.00 \mathrm{c}$ & 15 & 20.00 & $160.41 \pm 77.84 \mathrm{~b}$ & $128.33 \pm 141.45 b$ & $\mathrm{R}$ \\
\hline CR1-01-001 & $15.37 \pm 8.35 b$ & $50.00 \pm 10.00 b$ & 18.70 & 53.33 & $296.52 \pm 162.61 b$ & $641.66 \pm 222.279 \mathrm{ab}$ & S \\
\hline BoC15 & $6.67 \pm 11.54 b$ & $46.66 \pm 5.77 b$ & 6.67 & 60.00 & $140.00 \pm 42.48 b$ & $396.66 \pm 20.20 b$ & $S$ \\
\hline CR1-13-049 & $8.33 \pm 14.43 b$ & $60.00 \pm 17.32 b$ & 8.33 & 76.66 & $87.50 \pm 51.55 b$ & $700.00 \pm 311.08 a b$ & S \\
\hline Gboma-PCM & $23.33 \pm 15.27 \mathrm{~b}$ & $50.00 \pm 10.00 \mathrm{~b}$ & 60.00 & 80.00 & $256.66 \pm 248.31 b$ & $571.66 \pm 165.40 \mathrm{ab}$ & $\mathrm{S}$ \\
\hline $\mathrm{P}$ & $<0.05$ & $<0.001$ & & & $<0.05$ & $<0.01$ & \\
\hline
\end{tabular}

Means within column with the same letters are not significantly different according to Student-Newmann-Keuls test with $\mathrm{P}=0.05$. E= Experimentation

\section{DISCUSSION}

One of the most effective crop disease control approaches is the use of resistant materials. In this study, the reaction of some tomato and Gboma cultivars was assessed. For the two crops, these reactions were variable against $R$. solanacearum. The results showed that the local cv. Tohounvi showed more wilted plants of tomato with an incidence varying between $66.66 \%$ and $70 \%$ during the dry and rainy periods respectively. The tomato cv. Tohounvi has previously been identified as susceptible to bacterial wilt after disease incidence records in the field varying between $72 \%$ and $100 \%$ (Sikirou et al., 2009). It is the most cultivated tomato cultivar for years by farmers because it is easier for farmer for self- seeds production. It wilts in all agroecological zones where $R$. solanacearum occurs in Benin. The current results demonstrate the high susceptibility of tomato cv. Tohounvi to the local strain and confirm its use as a susceptible test cultivar to $R$. solanacearum (Sikirou et al., 2017).

The tested cultivars pointed out some susceptible, moderately resistant and resistant tomato cultivars to $R$. solanacearum. These results corroborate those of N'guessan et al. (2012) who reported a variation in tomatoes susceptibility against bacterial wilt. It ranged from highly susceptible to more resistant varieties. According to Grimault et al. (1995) and Monma et al. (1997), resistance to bacterial wilt in tomato is due to dominant single or recessive genes. Moreover, Oliveira et al. (1999) reported additive effects of genes for bacterial wilt resistance. During the two stages of experimentation, no wilted plants of the cultivar HW7996 was observed. The reaction of this cultivar to the bacterium is related to the resistance genes that it holds. The variety HW7996 is reported as resistant to $R$. solanacearum by many authors (Grimault et al., 1995; Wang et al., 2000; Carmeille et al., 2006; Wicker et al., 2009). These previous results with regard to the behavior of tomato cv. HW7996 justify its choice as a reference resistant cultivar in this study. Our results confirm those of Hanson et al. (1998) who stated that the varieties HW7996, HW7997, CRA66 and TML114 are the main sources of resistance in tomato to bacterial wilt. They also claimed that among these varieties, HW7996 is resistant to R. solanacearum phylotype I and II. Among all tested tomato cultivars, only PADMA came as the closest to HW7996 in terms of resistance to wilt and was identified as a resistant cultivar to strain 19bLDC. The Acc 99, Acc 151, Hy 5 and Sweet 72 genotypes have been reported resistant to $R$. solanacearum by Tewari (1986). Similar results were obtained for tomato cultivars Sonali (Patil et al., 1990), BWR-1 and BWR-5 (Bora et al., 1993) and BT-18 (Mishra et al., 1995). Sharma et al. (2006) identified resistance genes to bacterial wilt in cultivars Swarna Naveen, Swarna Lalima and B-17. Scott et al. (2009) also demonstrated a high level of resistance to $R$. solanacearum in large fruit breeding tomato lines from eight crosses of the F5 generation.

All tested tomato cultivars have been colonized by the bacteria. The cv. PADMA which appeared as resistant with no wilted plants was colonized at $80 \%$ by the bacteria during the second experimentation. This can be explained by the latency of $R$. solanacearum in resistant tomato cultivars vessels as reported by Prior et al. (1989). The fact that several resistant species and genotypes can harbor the pathogen without showing symptoms have already been reported (Jyothi et al., 2012). Unlike PADMA, the cv. HW7996 was not colonized by the used isolate during the first experiment. According to Prior et al. (1996), resistance to bacterial wilt results from the nonpenetration of the bacteria into the plant or from its less propagation in vascular tissues.

For Gboma, this study reports for the first time its reaction to bacterial wilt during screening test. The 
cultivars Gboma-Athiémé, CR1-01-001, BOC15, CR1-13049 and Gboma-PCM were susceptible with an incidence varying between $36.66 \%$ and $60 \%$. The Gboma cultivar AUB3G was resistant to the disease. The susceptibility of cv.Gboma-PCM (the most cultivated cultivar) to the bacterial wilt caused by R. solanacearum was reported by Sikirou et al. (2015b). Moreover, all tested Gboma cultivars were colonized by $R$. solanacearum. This result assumes that these Gboma cultivars tested in this study are penetrated by the bacterium $R$. solanacearum. This suggests that farmers have to avoid burying plants residues after harvesting tomato and Gboma as green manure in soils to avoid increasing soil inoculum for subsequent crops susceptible to R. solanacearum.

For tomato or Gboma cultivars, incidences as well as percentages of colonized plants by $R$. solanacearum were low during the first experiment installed in fresh period $\left(27.65{ }^{\circ} \mathrm{C}\right)$ and high during the second experiment installed in a dry period $\left(29.50^{\circ} \mathrm{C}\right)$. This finding confirms many previous results which demonstrated that temperature and humidity are the main development and multiplication factors of phytopathogenic bacteria. The general increasing of bacterial wilt incidence and colonized plant percentage may be due to the upward temperature variation which favored the multiplication of bacteria in plant stems. Also, in the dry season, with the low available water at soil level, plants absorb more individuals of $R$. solanacearum through the roots by drawing up the soil water. The same phenomenon had been reported by Techawongstien et al. (2009) who noted that bacterial wilt of tomatoes is more severe in the dry season than in the rainy season for tomato plants installed on infected soils.

\section{CONCLUSION}

Tomato and Gboma cultivars show variations in their resistance response to $R$. solanacearum. Two tomato cultivars HW7996 and PADMA were found highly resistant, one Platinum was resistant, and three Jalani, Thorgal and Mongal were found as moderately resistant. One Gboma cultivar AUB3G appeared resistant to $R$. solanacearum. The moderately resistant cultivars are recommended for cultivation under integrated production systems. New resistant tomato and Gboma cultivars are to be developed to increase the number of available resistant cultivars in Benin.

\section{ACKNOWLEDGEMENTS}

The authors are grateful to the International Fertilizer Development Center (IFDC), Centre International de
Recherche pour l'Agriculture et le Développement (CIRAD), National Agricultural Research Center (CNRA/Ivory Coast), Crops Research Institute of Ghana (CRI) and farmers for providing tomato and Gboma seeds.

\section{REFERENCES}

Affokpon, A., D. L. Coyne, L. Lawouin, C. Tossou, R. D. Agbèdè and J. Coosemans. 2011. Effectiveness of native West African arbuscular mycorrhizal fungi in protecting vegetable crops against root-knot nematodes. Biology and Fertility of Soils, 47: 207-217.

Artal, R. B., C. Gopalakrishnan and B. Thippeswamy. 2012. An efficient inoculation method to screen tomato, brinjal and chilli entries for bacterial wilt resistance. Pest Management in Horticultural Ecosystems, 18: 70-73.

Aslam, M. N., T. Mukhtar, M. A. Hussain and M. Raheel. 2017. Assessment of resistance to bacterial wilt incited by Ralstonia solanacearum in tomato germplasm. Journal of Plant Diseases and Protection, 124: 585-590.

Ayana, G. and C. Fininsa. 2017. Effect of crop rotation on tomato bacterial wilt (Ralstonia solanacearum) and survival of the pathogen in the rhizospheres and roots of different crops in Ethiopia. International Journal of Phytopathology, 5: 81-88.

Balestra, G., A. Heydari, D. Ceccarelli, E. Ovidi and A. Quattrucci. 2009. Antibacterial effect of Allium sativum and Ficus carica extracts on tomato bacterial pathogens. Crop Protection, 28: 807 811.

Bhowmik, D., K. S. Kumar, S. Paswan and S. Srivastava. 2012. Tomato-a natural medicine and its health benefits. Journal of Pharmacognosy and Phytochemistry, 1: 33-43.

Bora, G., A. Shadeque, L. Bora and A. Phookan. 1993. Evaluation of some tomato genotypes for variability and bacterial wilt resistance. Vegetable Science, 20: 44-47.

Boshou, L. 2005. A broad review and perspective on breeding for resistance to bacterial wilt. In: Allen C, P. Prior, A. C. Hayward (eds), Bacterial wilt disease and the Ralstonia solanacearum species complex. APS Press, St Paul, Minnesota, USA, pp 225-238.

Carmeille, A., C. Caranta, J. Dintinger, P. Prior, J. Luisetti, P. Besse. 2006. Identification of QTLs for 
Ralstonia solanacearum race 3-phylotype II resistance in tomato. Theoretical and Applied Genetics, 113: 110-121.

Comes, S., A. Fanigliulo, R. Pacella and A. Crescenzi. 2009. Severe outbreak of tomato yellow leaf curl Sardinia virus on pepper in southern Italy. Communications in agricultural and applied biological sciences, 74: 913-916.

Deberdt, P., R. Coranson Beaudu and B. Perrin. 2014. Le potentiel de biodésinfection des sols par les extraits naturels végétaux: utilisation des Alliacées dans la gestion du flétrissement bactérien de la tomate. Les Cahiers du CAEC, 12: 9-12.

Elphinstone, J., J. Hennessy, J. Wilson and D. Stead. 1996. Sensitivity of different methods for the detection of Ralstonia solanacearum in potato tuber extracts. Eppo Bulletin, 26: 663-678.

Francoise, A.-K., A. Prudent, A. Enoch, S. Rachidatou, B. Adrien, A. Charlotte, A. Victoire, V. Raymond and A. Ayémou. 2007. Pratiques culturales et teneur en éléments anti nutritionnels (nitrates et pesticides) du Solanum macrocarpum au sud du Bénin. African journal of food, agriculture, nutrition and development, 7: 1-21.

Grimault, V., P. Prior and G. Anais. 1995. A monogenic dominant resistance of tomato to bacterial wilt in Hawaii 7996 is associated with plant colonization by Pseudomonas solanacearum. Journal of Phytopathology, 143: 349-352.

Habetewold, K., K. Bekelle, S. Kasahun and H. Tariku. 2015. Prevalence of bacterial wilt of ginger (Zingiber Officinale) caused by Ralstonia Solansearum (Smith) in Ethiopia. International Journal of Research Studies in Agricultural Sciences, 6: 14-22.

Hanson, P. M., O. Licardo, J.-F. Wang and J.-T. Chen. 1998. Diallel analysis of bacterial wilt resistance in tomato derived from different sources. Plant disease, 82: 74-78.

Hanssen, I. M., M. Lapidot and B. P. Thomma. 2010. Emerging viral diseases of tomato crops. Molecular plant-microbe interactions, 23: 539548.

Hong, J. C., D. J. Norman, D. L. Reed, M. T. Momol and J. B. Jones. 2012. Diversity among Ralstonia solanacearum strains isolated from the southeastern United States. Phytopathology, 102:
924-936

Idrissou-Toure, M., R. Sikirou, B. Zocli, S. Bello, F. Oussou and M. E. Dossoumou. 2017. Efficacite de l'hydroxyde de cuivre contre la nervation noire $\mathrm{du}$ chou (Brassica oleracea l.) Causee par la bacterie Xanthomonas campestris pv. Campestris. Agronomie Africaine, 29: 149-157.

James, B., C. Atcha-Ahowé, I. Godonou, H. Baimey, H. Goergen, R. Sikirou and M. Toko. 2010. Integrated pest management in vegetable production: A guide for extension workers in West Africa. IITA. Pp. 1-45.

Jeger, M. and S. Viljanen-Rollinson. 2001. The use of the area under the disease-progress curve (AUDPC) to assess quantitative disease resistance in crop cultivars. Theoretical and Applied Genetics, 102: 32-40.

Jyothi, H. and H. Santhosha. 2012. Recent advances in breeding for bacterial wilt (Ralstonia solanacearum) resistance in tomato-review. Current Biotica, 6: 370-398.

Kakuhenzire, R., B. Lemaga, I. Kashaija, O. Ortiz and B. Mateeka. 2013. Effect of Crotalaria falcata in crop rotation and fallowing on potato bacterial wilt incidence, disease severity and latent infection in tubers and field soil. Biopesticides International, 9: 182-194.

Madden, L. V. a. M. W. 2003. The threat of plant pathogens as weapons against U.S. crops. Annual Review of Phytopathology, 41: 155-176.

Mew, T. and W. Ho. 1977. Effect of soil temperature on resistance of tomato cultivars to bacterial wilt. Phytopathology, 67: 909-911.

Mishra, A. 1995. Assessment of yield loss due to wilting in some popular tomato cultivars. Environment and Ecology, 13: 287-287.

Monma S., Y. S., H. Matsunaga. 1997. Héritage et efficacité de sélection de la résistance au flétrissement bactérien chez la tomate. Japan Agricultural Research Quarterly, 31: 195-204.

Muthoni, J., H. Shimelis and R. Melis. 2012. Management of bacterial wilt [Rhalstonia solanacearum Yabuuchi et al., 1995] of Potatoes: Opportunity for host resistance in Kenya. Journal of Agricultural Science, 4: 64-78.

N'guessan, C. A., K. Abo, L. Fondio, F. Chiroleu, A. Lebeau, S. Poussier, E. Wicker, D. Koné. 2012. So near and yet so far: the specific case of Ralstonia 
solanacearum populations from Côte d'Ivoire in Africa. Phytopathology, 102: 733-740.

Olaniyi, J., W. Akanbi, T. Adejumo and O. Ak. 2010. Growth, fruit yield and nutritional quality of tomato varieties. African Journal of Food Science, 4: 398-402.

Oliveira, W., L. Giordano and C. Lopes. 1999. Inheritance of resistance to bacterial wilt in tomato. Fitopatologia Brasileira, 24:49-53.

Patil, B., J. Rajput, S. Palve, A. Jambhale and M. Diwakar. 1990. New tomato'Sonali'high yielding and wilt resistant. Indian Horticulture, 35: 6-9.

Pereira-Carvalho, R., L. Boiteux, M. Fonseca, J. Díaz-Pendón, E. Moriones, R. Fernández-Muñoz, J. Charchar and R. Resende. 2010. Multiple resistance to Meloidogyne spp. and to bipartite and monopartite Begomovirus spp. in wild Solanum Lycopersicon accessions. Plant disease, 94: 179-185.

Prior, P., M. Béramis, M. Chillet, J. Schmit. 1989. Mise au point sur la lutte intégrée contre le flétrissement bactérien dû à Pseudomonas solanacearum E.F Smith aux Antilles française. 25th Annual Meeting. CFCS-Caribbean Food Crop Society, Gosier, Guadeloupe: 521-534. .

Prior, P., S. Bart, S. Leclercq, A. Darrasse and G. Anais. 1996. Resistance to bacterial wilt in tomato as discerned by spread of Pseudomonas (Burholderia) solanacearum in the stem tissues. Plant Pathology, 45: 720-726.

Rivard, C., S. O'connell, M. Peet, R. Welker and F. Louws. 2012. Grafting tomato to manage bacterial wilt caused by Ralstonia solanacearum in the southeastern United States. Plant disease, 96: 973-978.

Scott, J., G. Vallad and J. Jones. 2007. High level of resistance to bacterial wilt (Ralstonia solanacearum) obtained in large-fruited tomato breeding lines derived from Hawaii 7997. II International Symposium on Tomato Diseases, 808: 269-274.

Sharma, J., A. Jha, A. Singh, R. Pan, M. Rai and S. Kumar. 2006. Evaluation of tomato against bacterial wilt (Ralstonia solanacearum) in Jharkhand. Indian Phytopathology, 59: 405-409.

Sikirou, R. 2015. Geographical distribution and prevalence of the main tomato fungal wilt diseases in Benin. International Journal of Biological and Chemical Sciences, 9: 603-613.
Sikirou, R., B. Zocli, M. Paret, P. Deberdt, R. CoransonBeaudu, J. Huat, F. Assogba-Komlan, M. Dossoumou, S. Simon and E. Wicker. 2015. First report of bacterial wilt of Gboma (Solanum macrocarpon) caused by Ralstonia solanacearum in Benin. Plant Disease, 99: 1640-1640.

Sikirou, R., F. Beed, V. Ezin, G. Gbehounou, S. A. Miller, K. Wydra. 2011. Localisation du flétrissement bactérien de la tomate, une maladie dangereuse des solanacées au Bénin. Fiche technique, dépôt légal $N^{\circ} 5529$ 4ème trimestre 2011, Bibliothèque Nationale (BN) du Bénin.

Sikirou, R., F. Beed, V. Ezin, G. Gbehounou, S. Miller and K. Wydra. 2009. First report of bacterial wilt of tomato (Solanum lycopersicum) caused by Ralstonia solanacearum in Benin. Plant disease, 93: 549-549.

Sikirou, R., F. Beed, V. Ezin, J. Hoteigni and S. A. Miller. 2017. Distribution, pathological and biochemical characterization of Ralstonia solanacearum in Benin. Annals of Agricultural Sciences, 62: 83-88.

Sikirou, R., L. Afouda, A. Zannou, G. Gbèhounou and F. Komlan. 2001. Diagnostic des problèmes phytosanitaires des cultures maraichères au Sud Bénin: cas de la tomate, du piment, de l'oignon et $\mathrm{du}$ gombo. Acte de l'atelier scientifique Sud et Centre tenu du, 12: 102-105.

Simeni, G., R. Adeoti, E. Abiassi, M. Kodjo and 0. Coulibaly. 2009. Caractérisation des systèmes de cultures maraîchères des zones urbaine et périurbaine dans la ville de Djougou au NordOuest du Bénin. Bulletin de la Recherche Agronomique du Bénin, 64: 34-49.

Subedi, N. and S. Miller. 2014. Resistance of a worldwide collection of resistant tomato, eggplant and pepper lines to South Asian strains of Ralstonia solanacearum. Phytopathology. amer Phytopathological Society 3340 Pilot Knob Road, st Paul, mn 55121 USA, pp. 115-115.

Techawongstien, S., P. Thummabenjapone and H. Bolkan. 2007. Screening tomato varieties for their bacterial wilt resistance over seasons in Northeast Thailand. II International Symposium on Tomato Diseases, 808: 263-268.

Tengku Abdul Malik, T. M., M. N. Mohamad Roff, L. Rozeita, T. Maimun. 2012. Status of distribution, damage and mitigation of bacterial wilt in Malaysia. Hoticulture Research Centre, MARDI, 
Serdang, Selangor, Malaysia.

Tewari, A. 1986. A note on the evaluation of tomato genotypes for resistance to bacterial wilt (Pseudomonas solanacearum). Vegetable Science, 17:196-198.

Vasse, J., P. Frey and A. Trigalet. 1995. Microscopic studies of intercellular infection and protoxylem invasion of tomato roots by Pseudomonas solanacearum. Molecular Plant-Microbe Interactions, 8: 241-251.

Wang, J.-F., J. Olivier, P. Thoquet, B. Mangin, L. Sauviac and N. H. Grimsley. 2000. Resistance of tomato line Hawaii7996 to Ralstonia solanacearum Pss4 in Taiwan is controlled mainly by a major strainspecific locus. Molecular plant-microbe interactions, 13: 6-13.

Wicker, E., R. Coranson-Beaudu, S. Cadasse and M.-A. William. 2007. Emerging strains of Ralstonia solanacearum in the French West Indies raise new challenges to tomato breeders. II International Symposium on Tomato Diseases, 808: 279-286.

\section{Contribution of Authors:}

Ghislain F. G. N. Oussou

Rachidatou Sikirou

Sètondji A. P. E. Afoha

Marie E. E. A. Dossoumou

Sharif A. Boukari

Françoise A. Komlan

Bruno Zocli
:

: All authors have equally contribution in writing manuscript. 